\title{
Motivating Students on ICT-related Study Programs to Engage with the Subject of Sustainable Development
}

\author{
Lorenz M. Hilty", Patrizia Huber
}

\begin{abstract}
Purpose - Sustainable development (SD) does not usually form part of the curriculum of ICTrelated study programs such as Computer Science, Information Technology, Information Systems, or Informatics. However, many topics form a bridge between SD and ICT and could potentially be integrated into ICT-related study programs. This paper reports the findings of a study into which specific topics in the field of SD have the greatest potential to motivate students on ICT-related study programs to engage with the topic of sustainability.
\end{abstract}

Design/methodology/approach - In this exploratory study the authors evaluated Bachelor's and Master's courses that introduced the topic of SD to students on ICT-related study programs. The evaluation focuses on the insights that the students gained into sustainability and the extent to which their motivation to engage with the subject was increased. The evaluation combines qualitative and quantitative approaches.

Findings - The authors identify five thematic clusters with the greatest potential to motivate students to engage with the topic of sustainability: (1) A conceptual model of the positive and negative impacts of ICT; (2) Reports on the recycling of ICT hardware; (3) Examples of using ICT to reduce greenhouse gas emissions, with a focus on the substitution of virtual for physical presence; (4) Statistical data on post-industrial, seemingly dematerialized economies and the contradiction with regard to the total material demand of such economies; and (5) Evidence for rebound effects that lead to increasing demand for goods or services that are produced with less energy input or can be consumed faster.

Originality/value - ICT is a transformational and to a certain extent disruptive technology. It is therefore important to discuss the development of ICT and its applications in the context of SD. Several authors have pointed out the need to integrate the topic of sustainability into ICT courses at universities and similar, but few have discussed how this can be done in practice. Our study is the first to explore which topics have the greatest potential to motivate students on ICT-related programs to engage with the area of SD.

Keywords Sustainable Development, Information and Communication Technology, ICT for Sustainability (ICT4S), Higher Education, Education for Sustainable Development, Motivation

Paper type Research Paper

\section{INTRODUCTION}

The digital transformation is causing society to change at a rapid pace. Communication infrastructure, communication practices, patterns of consumption and production - all of these

\footnotetext{
* Corresponding author: Lorenz M. Hilty, University of Zurich, Empa Materials Science and Technology and KTH, hilty@ifi.uzh.ch
} 
Accepted author manuscript of the article:

Lorenz M. Hilty, Patrizia Huber, (2017) "Motivating students on ICT-related study programs to engage with the subject of sustainable development", International Journal of

Sustainability in Higher Education, https://doi.org/10.1108/IJSHE-02-2017-0027

areas are in transition. Yet although the transformational power of digital information and communication technologies (ICT) is widely acknowledged, there is no broad debate about the end goal of this transformation. The emerging research field called "ICT for Sustainability" explicitly addresses the question of how to align digitalization with sustainable development (Hilty and Hercheui, 2010; Hilty and Aebischer, 2015). The ICT industry and NGOs have been pointing out the contribution of ICT to the reduction of greenhouse gas emissions (GeSI, 2012; GeSI, 2015; Hilty and Bieser, 2017). The OECD has investigated the role of ICT in creating a greener economy (Mickoleit, 2010), and complex models have been developed to investigate the effect of ICT on energy and the environment (Laitner et al., 2009; Hilty et al., 2004; Erdmann and Hilty, 2010) and broader visions of a sustainable information society based on the precautionary principle have been formulated (Som et al, 2009). In order to promote these ideas in higher education, it seems important to include the topic of sustainable development into ICT-related study programs.

Several scholars have pointed out the necessity to reflect the relationship between ICT and sustainability in an educational context. Klimova et al. (2016) address the educational sector as a "key player in the successful transition to a knowledge-based economy and society" and derive from this role the "responsibility to address challenges associated with the use of ICT for sustainability" (Klimova et al. 2016, 224). In a similar vein, Cai (2010) assigns a special responsibilty for sustainability and the green movement to the computing field and presents strategies to integrate the topic of sustainability into undergraduate computing education.

Mann et al. (2015) demand to transform the profession of ICT to one of "contributing to a sustainable future", which requires the education of students who "think and act as sustainable practitioners in computing" (Mann et al., 2015, 229). Similar claims have been made by Pargman and Eriksson (2013) with regard to engeneering education in general and Media Technology Education in particular, by Easterbrook (2014), who points out the gap between computational thinking and systems thinking (as it is demanded for sustainability), and Özkan and Mishra (2015), who seek to integrate education on sustainability in the ICT curriculum.

In the project "Motivating Students of Information Systems, Information Technology and Computer Science for Sustainability - Developing and Testing Course Material" reported here, ${ }^{\dagger}$ we investigated what content has the greatest potential to motivate students on ICTrelated study programs to reflect upon and engage in Sustainable Development (SD). The research aimed to help bridge the gap between the intention to raise awareness about SD in higher education by integrating SD-related content into syllabuses, and the actual impact of attempts to do so.

This project arose from a series of lectures given by the first author of this paper at the University of Zurich (UZH) and KTH Stockholm (KTH). The lectures in question provided an introduction to the relationship between ICT systems and issues relating to SD. They were based on current discourse in the fields of "Green IT" or "Green ICT", "Environmental Informatics" and similar fields that can be subsumed under the umbrella term "ICT for Sustainability", or "ICT4S" for short (Hilty and Aebischer, 2015). The lectures were offered as

+ The project is part of the Sustainable Development at Universities Program: http://www.sd-universities.ch/sd-universities/Aboutthe-programme.html 
Accepted author manuscript of the article:

Lorenz M. Hilty, Patrizia Huber, (2017) "Motivating students on ICT-related study programs

to engage with the subject of sustainable development", International Journal of

Sustainability in Higher Education, https://doi.org/10.1108/IJSHE-02-2017-0027

a regular part of the course "Informatics and Sustainable Development" (MINF9519) at UZH and as guest lectures in the courses "Sustainable Development for Computer Science and Engineering" (AG1814) and "Sustainable Development, ICT and Innovation" (AG1815) at KTH in 2014 and 2015.

The teaching material used in the courses had evolved over several years. The same material (with some adaptations to the context) was used in all lectures studied in this project. The project reported here provided an opportunity to systematically evaluate the extent to which the materials motivated students to engage with the topic of SD, and to improve this impact based on empirical evidence. The project was conducted between September 2014 and June 2016.

\section{RELATED WORK}

A small but growing body of literature addresses the topic of Education for Sustainable Development (ESD) in the context of ICT, specifically at university level. Below, the state of the discourse at present is summarized, as far as it is relevant to our project.

Pargman and Eriksson (2013) point out a lack of teaching material bridging the gap between SD and ICT, in particular that there are "no suitable textbooks about sustainability specifically for engineering students studying ICT and/or media" (Pargman and Eriksson, 2013, 6). In a more recent paper, the same authors describe their experiences integrating the topic of sustainability - and specifically ICT4S - into a media technology engineering program at KTH Stockholm. The paper focuses on the motivation of the students to connect the topic of sustainability with their everyday lives. The authors argue that in order to make the subject relevant for students, sustainability has to be tightly connected to their own domain: "If it doesn't relate to other subject areas in the education, or topics that the students in question take an interest in, it can easily become (yet another) course to 'get through' and 'tick off' without it having any measurable impact on the students' thinking or their future actions as ICT professionals" (Eriksson and Pargman, 2014, 42). They argue that it is therefore necessary to find a balance between teaching about sustainability in general and teaching about ICT4S in particular. Furthermore, Eriksson and Pargman examine which aspects of the interdisciplinary field of ICT4S are most relevant when teaching media technology students and how the connection between ICT and sustainability can be clarified and expressed in such a way "that it becomes both relevant and possible for these students to relate to it" (Eriksson and Pargman, 2014, 40). Based on qualitative and quantitative data from the course "Sustainability and Media Technology" at KTH, they report that, at the end of the course, many students showed an increased commitment to sustainability compared with the beginning of the course. Students expressed a desire to find ways to promote sustainability within the area of ICT (including media technology). The authors conclude that more concrete examples of how ICT can be used to work towards sustainability would be desirable (Eriksson and Pargman, 2014).

Easterbrook (2014) highlights the role of "systems thinking" in the teaching of sustainability in the context of ICT. In his view, systems thinking forms the required bridge between computational thinking and sustainable practice: "it provides a domain ontology for reasoning about sustainability, a conceptual basis for reasoning about transformational change, and a 
Accepted author manuscript of the article:

Lorenz M. Hilty, Patrizia Huber, (2017) "Motivating students on ICT-related study programs to engage with the subject of sustainable development", International Journal of

Sustainability in Higher Education, https://doi.org/10.1108/IJSHE-02-2017-0027

set of methods for critical thinking about the social and environmental impacts of technology" (Easterbrook, 2014, 235). He further points out that "computer professionals may attempt to solve all problems through algorithmic means, while failing to perceive those that cannot be expressed using the abstractions of [computational thinking]. The computational thinker looks for problems that can be tackled with computers. Immediately, this provides a selective lens through which to view the world" (Easterbrook, 2014, 236). Easterbrook believes that problems that are unlikely to have computational solutions, such as social developments, value judgments, and ethical dilemmas, tend to be ignored by purely computational thinking, whereas systems thinking connects computational thinking with these types of problems. Therefore, systems thinking should be part of "any attempt to bring about transformational change to a sustainable society" and, more specifically, form the "conceptual basis for designing ICT for sustainability" (Easterbrook, 2014, 239).

This can be viewed as a specialization (for the ICT field) of Sterling's (2004) systemic view of sustainability in education. Sterling argues that sustainability requires "transformative learning" or "epistemic learning", a type of learning offering alternative operative paradigms in the sense of not only "doing things better" (first learning level) or "doing better things" (second learning level) but „seeing things differently". In other words, there would be a shift from „learning about change" to "education for change" to "learning as change" or "sustainable education" (Sterling, 2004).

Issa et al. (2014) focus on "Green IT" principles and strategies to encourage students' critical thinking about ICT. They developed a postgraduate unit to spread the awareness of what they call "sustainable computing" among Information Systems Master's students and assessed the students' reactions to identify how the unit can raise their awareness of sustainability and how it assists them to change their attitudes to ICT usage. The study is based on quantitative and qualitative data from 36 students who provided formal (learning outcomes, experience and resources, assessments, feedback workload teaching style, motivation, effectiveness and overall student satisfaction) and informal feedback (students were asked to provide their anonymous feedback on the unit during the semester). The results show that the unit raised the students' awareness of sustainability issues and provided them with some knowledge about Green IT, related strategies, risks and opportunities, and the threats and problems posed by ICT in developed and developing countries. Their completion of the unit encouraged them to reflect upon and take action to address the problems associated with technology usage (Issa et al., 2014)

Özkan and Mishra (2015) present a curriculum for what they call "sustainable ICT" along with its expected learning outcomes and components. The curriculum is a response to the increasing interest in teaching sustainability within engineering and ICT-related educational programs. The main challenges in providing and teaching such curricula are, in their view, as follows:

- To interest students and faculty in the topic of sustainability

- To identify spheres of activity for IT professionals

- To build up competence fields for solutions

- To incorporate the topic of sustainability into syllabuses 
Accepted author manuscript of the article:

Lorenz M. Hilty, Patrizia Huber, (2017) "Motivating students on ICT-related study programs

to engage with the subject of sustainable development", International Journal of

Sustainability in Higher Education, https://doi.org/10.1108/IJSHE-02-2017-0027

They suggest including the "technical, economic, humanitarian and societal concerns of sustainability" in the curriculum, embedded in a paradigm of systems thinking. In their approach, the role of systems thinking is to enable the individual to analyze "isolated ICT effects within the system" and to "see this problem system as part of another system that influences it" (Özkan and Mishra, 2015, 98).

The following two studies - Drayson et al. (2013) and Mulder et al. (2015) - are included in the related work due to their indirect relevance for our research although they do not focus specifically on ICT-related study programs.

In a longitudinal study of students' attitudes towards SD in UK, Drayson et al. (2013) found that two-thirds of respondents consistently believe that SD should be incorporated into all university courses. They report a continuous desire among students for a reframing of curriculum content, rather than additional content courses. Further, their results "suggest a demand for employability, and sustainability skills, to be developed in a way that is relevant to chosen subject area, reinforcing a need for teaching and learning on SD to be targeted rather than generalised" (Drayson et al. 2013, 49). Transferred to the more specific context of our study, this suggests that students could be more interested in content on SD if it is clearly related to their (ICT-related) subject area and provides them with skills they expect to be of practical relevance.

Mulder et al. (2015) discuss how students and lecturers can be motivated to engage with the topic of SD, and what arrangements with regard to teaching and learning are required for this to take place. The authors explore, from a psychological point of view, which "motivators" have the potential to persuade or move people to perform certain actions. They also examine how information should be presented and what kind of emotions should be evoked to trigger concrete actions. They conclude that attempting to motivate students and lecturers by only speaking about catastrophes (i.e. the negative impact of failing to take SD seriously) is ineffective. A more effective approach, in their view, is to cite scientific facts in a neutral tone and discuss what action is possible (Mulder et al., 2015).To summarize, integrating sustainability into ICT-related programs involves transformation at both the individual and the institutional levels. Among other things, transformation depends on the motivation of people to change their perspective and to explore new ways of thinking and acting. The literature review shows that little is known about what students on ICT-related programs retain from courses about sustainability, and what content motivates them to contribute to sustainability in their private and later professional lives. Our exploratory study helps fill this gap by addressing the issue of motivation from the perspective of students, focusing on the insights students of ICTrelated subject areas (in particular on ICT-related programs) gain from courses addressing sustainability, and what content motivates them to engage with sustainability.

\section{RESEARCH QUESTIONS}

The question of how to motivate students to engage with the topic of SD in teaching and learning has two aspects: one relates to content, the other to methods. The current project is focused on the content the students learn and the potential of this content to motivate them to 
engage with sustainability, as we believe that this is a necessary first step before teaching methods can be addressed.

We recognise that a comprehensive teaching and learning arrangement consists both of content and pedagogical method and that the method is important as a motivational factor. However, as long as there is no established content in a given field, we consider it an adequate forst step to focus on content and search for content that is able to change the student's views, even though the teaching method is modulating the effect we are observing. This approach is inline with Klafki's (1967) didactics, where the identification of content that is meaningful to the students is a necessary first step in preparing for teaching. This exploratory study is not intended to reveal insights about the relative importance of content versus method.

Our research questions $(R Q)$ are as follows:

RQ1: What insights about sustainability do students gain from the lectures?

RQ2: Which of these insights motivate the students to engage with sustainability within their (ICT-related) field of study?

RQ3: Which of these insights motivate the students to engage with sustainability in general?

The focus of the research is thus to find out what content changed their views about sustainability and whether this had an effect on their motivation to engage with sustainability, both within their field of study and outside it.

\section{METHODS}

The field of education for sustainable development (ESD) in the specific context of ICT-related study programs is not yet mature enough for hypothesis-testing. This study therefore uses cluster analysis to discover structures within the data. To collect the data, we developed a questionnaire for asking students repeatedly about the main insights they gained from lectures about sustainability aspects of ICT and wether these insights motivated them to engage with the topic of SD. The respondents stayed anomymous, they just had to provide a self-chosen pseudonym to enable us to link questionnaires filled in by the same person after different lessons.

\section{Subjects}

A total of 80 students took part in the study: 23 specializing in Information Systems or Software Engineering in any year of the Master's in Informatics at UZH, and 57 students in their third year, first study cycle, of Computer Engineering, Electronics and Computer Engineering or Information and Communication Technology at KTH.

The subjects from UZH took the course "Informatics and Sustainable Development" (MINF9519) in the Winter Semester of 2014. The subjects from KTH took the course "Sustainable Development, ICT and Innovation" (AG1815) in the Summer Semester of 2015. They were asked to fill out online questionnaires while the course was in progress, and all participating students complied. 
Lorenz M. Hilty, Patrizia Huber, (2017) "Motivating students on ICT-related study programs to engage with the subject of sustainable development", International Journal of

Sustainability in Higher Education, https://doi.org/10.1108/IJSHE-02-2017-0027

The subjects from UZH were 23 Master's students ( 3 female, 20 male) ranging in age from 22 to 34 (mean: 25.9 years old). The subjects from KTH were 57 Bachelor's and Master's students ( 9 female, 47 male, 1 unknown) aged 20 to 29 (mean: 22.5 years old).

\section{Materials and Procedure}

The course at $\mathrm{UZH}$ comprised seven lectures during the semester, while the course at KTH took place on a single day. The materials consisted of pre-existing course material for the lecture plus a series of online questionnaires. Because the course at KTH was shorter and given in a single block, it only used part of the course materials.

Feedback was collected via online questionnaires, developed and tested in advance. Subjects were given as much time as they needed to complete the questionnaires. The questionnaires were anonymous but subjects were requested to enter a pseudonym (the same for all questionnaires) to allow us to link the questionnaires that came from the same subject. Because the data was not linked to the students' identities as they were using pseudonyms, the assumption seems justified that their answers were honest and not biased by social desirability.

After each lecture, subjects were asked to formulate up to three insights related to sustainability that they had gained during the lecture. They were also asked them to assess each of these insights with regard to a set of criteria, using a five-point Likert scale ("strongly agree," "agree," "neither agree nor disagree," "disagree," "strongly disagree"). Two Likert items directly addressed the impact of the insights with regard to how they motivated students to contribute to sustainability:

- $\quad$ "This insight motivates me to contribute more to sustainability especially in the field of ICT"

- "This insight motivates me to contribute more to sustainability in general"

These two items directly correspond to RQ2 and RQ3. Furthermore, the following items were included to find out more about the relevance the subjects attribute to their insights, both within the course and outside it:

- "This insight is a necessary part of this course"

- "This insight motivates me to learn more on the topic"

- "This insight should be known to every ICT professional"

- "This insight should be known to every person interested in sustainability"

- "This insight should be generally known"

The full questionnaire is included in the supporting information (Hilty and Huber, 2017).

\section{Data Analysis}

This section describes the procedure that was used to analyze the insights that the students reported. We identified those insights with the greatest potential to motivate the students to 
engage with sustainability, and classified all the insights with regard to their content into "semantic clusters".

An "insight" in the context of this study means a statement provided by a student when asked to list the insights they gained from the course. By amassing all the information from the questionnaires, we assembled 275 records containing insights. We then manually removed 10 records from the dataset because they contained information that was obviously based on a misunderstanding of the contents of the course, in the opinion of the lecturer. This resulted in a dataset of 265 "meaningful" insights formulated by 80 subjects.

In a next step, these 265 insights were assessed with regard to their "motivation potential" based on the answers the students gave in the Likert-scale rating. We used the two items directly addressing the motivation to engage with sustainability as the main indicator for the "motivation potential for sustainability". So as not to rely solely on these two items, we also checked their interaction with other items related to motivation by computing Kendall rank correlation coefficients. 
Lorenz M. Hilty, Patrizia Huber, (2017) "Motivating students on ICT-related study programs to engage with the subject of sustainable development", International Journal of Sustainability in Higher Education, https://doi.org/10.1108/IJSHE-02-2017-0027

Table 1: Semantic variables derived from the content of the lecture, mainly based on the theoretical framework described by Hilty (2008) and Hilty and Aebischer (2015).

\begin{tabular}{|c|c|}
\hline ICT aspects & $\begin{array}{l}\text { 1. ICT systems } \\
\text { 2. ICT hardware } \\
\text { 3. ICT software }\end{array}$ \\
\hline ICT impact categories & $\begin{array}{l}\text { 4. 1st-order effects (ecological footprint of } \\
\text { ICT) } \\
\text { 5. 2nd-order effects (enabling impact of } \\
\text { ICT) } \\
\text { 6. } \begin{array}{l}\text { 3rd-order effects (systemic and } \\
\text { structural impact of ICT) }\end{array}\end{array}$ \\
\hline Specific areas of ICT impact & $\begin{array}{l}\text { 7. energy efficiency of production or } \\
\text { consumption } \\
\text { 8. time efficiency of production or } \\
\text { consumption } \\
\text { 9. consumer decisions } \\
\text { 10. structural change }\end{array}$ \\
\hline Aspects of sustainability & $\begin{array}{l}\text { 11. environmental impacts } \\
\text { 12. social impacts } \\
\text { 13. economic impacts }\end{array}$ \\
\hline Life-cycle thinking & $\begin{array}{l}\text { 14. Life-cycle approach in general } \\
\text { 15. Production stage } \\
\text { 16. Use stage } \\
\text { 17. End-of-life stage }\end{array}$ \\
\hline Aspects of social metabolism & $\begin{array}{l}\text { 18. material demand } \\
\text { 19. energy demand } \\
\text { 20. pollution } \\
\text { 21. global issues }\end{array}$ \\
\hline Type of content & $\begin{array}{l}\text { 22. conceptual framework } \\
\text { 23. method of analysis } \\
\text { 24. practical example }\end{array}$ \\
\hline
\end{tabular}

Based on the general picture that this method revealed, we then decided to apply a simple but robust rule to divide the insights into two groups: insights motivating students to engage with the topic of sustainability (henceforth "motivating insights" for short), and others (henceforth "non-motivating insights"). The rule was to count an insight as a motivating insight if at least one of the two main items was answered with "agree" or "strongly agree". 
In addition, the insights were classified into semantic clusters using a two-step procedure, consisting of a directed qualitative content analysis (Hsieh and Shannon, 2005) followed by a cluster analysis. The directed qualitative content analysis was carried out by predefining 24 variables based on the theoretical knowledge of the content of the course (see Table 1). Each text provided as an "insight" by a subject was then manually ranked according to what extent the aspect expressed by the variable was mentioned in the text. For example, the insight a student formulated as follows:

\section{Example 1: "Emissions saved by using video conferencing"}

was ranked high for the following variables:

- "ICT systems" (1) because videoconferencing systems are ICT systems

- "second-order effects (enabling the impact of ICT)" (5) because the focus of the insight is on the behavior that this application enables

- "environmental impacts" (11) because the focus is on reducing an environmental impact (emissions)

- "energy demand" (19) because the effect of ICT to reduce energy demand for travel was an implicit link in the causal chain underlying this insight

- "practical example" (24) because the insight was reported after a part of the lecture that provided a major practical example of videoconferencing. ${ }^{*}$

The insight was ranked medium on "social impacts" (12) and "pollution" (20), and low or zero on others. ${ }^{\S}$ Exactly the same vector was assigned when coding the following text, formulated by a different subject:

\section{Example 2: "IP-based videoconferencing can reduce emissions"}

This is essentially a paraphrase of Example 1. Thus, the vectors assigned to the insights by the directed content analysis can be used to calculate semantic distances between the insight formulations provided by the subjects. ${ }^{* *}$ This was then used to create an agglomerative cluster tree using the inner squared Euclidean distance ("minimum variance algorithm") according to the Ward method (Ward, 1963). A set of 34 clusters was created from the tree. This was found to be the smallest number of clusters that was still sufficient to avoid insights of obviously different content getting mixed up in one cluster, i.e., any smaller number of clusters led to an implausible merging of insights that obviously addressed very different topics.

\footnotetext{
${ }^{\ddagger}$ For more details, see Coroama et al. $(2012,2013)$.

$\S$ This decision requires some knowledge of the context. The part of the lecture to which this response referred focused on a specific type of emission, namely $\mathrm{CO}_{2}$ emissions caused by the use of fossil fuel, in particular for travel and electricity generation. It can be safely assumed that when referring to "emissions" the student was specifically referring to this type of emission. For this reason, "energy demand" was rated higher than "pollution". $\mathrm{CO}_{2}$ is not a pollutant in the strict sense. "Pollution" was only rated high in the context of toxic waste and toxic emissions, such as the impact of informal e-waste recycling. The same applies to the second example.

**The coding was done using a five-point Likert scale ("clearly mentioned", "mentioned", "somewhat mentioned", "remotely mentioned", "not mentioned"). The definition of the variables and the coding was done after the end of the course, by the lecturer, in the same way for the courses at UZH and KTH.
} 
The resulting 34 clusters were then given meaningful names, i.e., names that roughly indicate what the insights constituting that cluster are about, such as "Systems thinking: Exponential growth". Table 2 shows two examples of such clusters.

Cluster analysis was carried out independently of the classification into motivating and nonmotivating insights, as defined above. Motivating insights are marked with an asterisk $\left({ }^{*}\right)$ in Table 2. It can be seen that the first cluster ("Systems Thinking: Exponential Growth") contains both motivating and non-motivating insights, while the second one ("Rebound Effect: Energy") contains only motivating insights. The full list of clusters is given in the supporting information (Hilty and Huber, 2017).

Table 2: Examples of clusters produced by the cluster analysis. After the analysis, the clusters were given meaningful names based on the insights they contained (left column). Motivating insights are marked with an asterisk $\left(^{*}\right)$ in the examples below (right column).

\begin{tabular}{|l|l|}
\hline $\begin{array}{l}\text { Cluster name } \\
\text { assigned }\end{array}$ & $\begin{array}{l}\text { Insights contained in the cluster (verbatim excerpts from the } \\
\text { students' answers) }\end{array}$ \\
\hline $\begin{array}{l}\text { Cluster Example 1: } \\
\text { Systems thinking: } \\
\text { Exponential growth }\end{array}$ & "People cannot easily imagine exponential growth." * \\
\cline { 2 - 3 } & "Exponential growth is underestimated." \\
\cline { 2 - 3 } & "It is very difficult for people to realize how fast exponential growth is." \\
\cline { 2 - 3 } & $\begin{array}{l}\text { "Most people know only one tool to imagine the future.... linear } \\
\text { extrapolation." }\end{array}$ \\
\hline \multirow{2}{*}{$\begin{array}{l}\text { Cluster Example 2: } \\
\text { Energy }\end{array}$} & $\begin{array}{l}\text { "How much more power today's computers (servers) have and ... need } \\
\text { a lot less energy than before (-> much more efficient). But with this } \\
\text { comes an increased usage more power-consumption..." * }\end{array}$ \\
\cline { 2 - 3 } & "Developing something may (will) have impact on the opposite...." * \\
\cline { 2 - 3 } & "That the energy efficiency is not sufficient to achieve sufficiency." * \\
\cline { 2 - 3 } & "More energy efficiency can lead to more energy consumption." * \\
\hline
\end{tabular}

The analysis revealed that all 34 clusters contained at least one motivating insight. Removing the non-motivating insights from the clusters, the average number of insights per cluster fell from 7.8 to 5.5 . 
Since each cluster represents a semantic entity (i.e., a piece of meaningful content) that was considered insightful by some students, the final step in our exploratory analysis was to work out which of the 34 clusters where the most "motivating" with regard to sustainability. To identify these clusters, we selected those that motivated at least ten subjects to engage with sustainability. Exactly five clusters satisfied this condition. They will be called the "golden nuggets" throughout the remaining part of this article.

\section{RESULTS}

The statistical results regarding the interactions between questionnaire items show a clear picture, which will help us to simplify the rest of the analysis considerably, as will be shown below. A Kendall rank correlation test revealed that the two main items directly addressing the "motivational" effects of the insights in the field of ICT and in general were correlated $(\mathbf{T}=0.57$, $p<0.001)$. Table 3 also shows how the main items are correlated with additional items that could be indirectly relevant when judging motivation.

Table 3: Rank correlations between questionnaire items.

\begin{tabular}{|c|c|c|}
\hline $\begin{array}{l}\text { Likert items rated on a } \\
\text { five-point Likert scale }\end{array}$ & $\begin{array}{l}\text { "This insight motivates me to } \\
\text { contribute more to sustainability } \\
\text { especially in the field of ICT" }\end{array}$ & $\begin{array}{l}\text { "This insight motivates me to } \\
\text { contribute more to sustainability } \\
\text { in general" }\end{array}$ \\
\hline $\begin{array}{l}\text { "This insight is a } \\
\text { necessary part of this } \\
\text { course." }\end{array}$ & $\begin{array}{l}\mathbf{T}=0.35 \\
\mathrm{p}<0.001\end{array}$ & $\begin{array}{l}\mathbf{T}=0.41 \\
\mathrm{p}<0.001\end{array}$ \\
\hline $\begin{array}{l}\text { "This insight motivates me } \\
\text { to learn more on the } \\
\text { topic." }\end{array}$ & $\begin{array}{l}\mathbf{T}=0.35 \\
p<0.001\end{array}$ & $\begin{array}{l}\mathbf{T}=0.43 \\
p<0.001\end{array}$ \\
\hline $\begin{array}{l}\text { "This insight should be } \\
\text { known to every ICT } \\
\text { professional." }\end{array}$ & $\begin{array}{l}\mathbf{T}=0.42 \\
p<0.001\end{array}$ & $\begin{array}{l}\mathbf{T}=0.30 \\
\mathrm{p}<0.001\end{array}$ \\
\hline $\begin{array}{l}\text { "This insight should be } \\
\text { known to every person } \\
\text { interested in } \\
\text { sustainability." }\end{array}$ & $\begin{array}{l}\mathbf{T}=0.26 \\
p<0.001\end{array}$ & $\begin{array}{l}\mathbf{T}=0.33 \\
p<0.001\end{array}$ \\
\hline $\begin{array}{l}\text { "This insight should be } \\
\text { generally known." }\end{array}$ & $\begin{array}{l}\mathbf{T}=0.29 \\
\mathrm{p}<0.001\end{array}$ & $\begin{array}{l}\mathbf{T}=0.38 \\
p<0.001\end{array}$ \\
\hline
\end{tabular}


It therefore seems justified to use just the two main items ("...motivates me to contribute more to sustainability, especially in the field of ICT" and "...motivates me to contribute more to sustainability in general") to rank the insights for their potential to motivate students to engage with the topic of sustainability. Furthermore, the original distinction between these two items seems to be almost irrelevant, given their strong positive correlation. As a result, RQ2 and RQ3 can be merged into a single question, RQ2/3. This keeps the analysis simple, avoiding results at a level of precision not warranted by the data.

The answer to RQ1 ("What insights about sustainability do students gain from the lectures?") is a list of the 34 clusters, as mentioned above. This list is provided in the supporting information (Hilty and Huber, 2017).

The answer to RQ2/3 ("Which of these insights motivate the students for sustainability?") is given in Table 4. The table shows the "golden nuggets", i.e. the five clusters found to have the greatest potential to motivate subjects to engage with the topic of sustainability, according to the criteria described in the Methods section. 
Lorenz M. Hilty, Patrizia Huber, (2017) "Motivating students on ICT-related study programs to engage with the subject of sustainable development", International Journal of Sustainability in Higher Education, https://doi.org/10.1108/IJSHE-02-2017-0027

Table 4: The five clusters identified as "golden nuggets" in the exploratory study. These topics have proven to motivate students on ICT-related programmes at UZH and KTH to engage with the subject of sustainability.

\begin{tabular}{|c|c|c|}
\hline Cluster name & Description of lecture content & $\begin{array}{l}\text { Example of an insight } \\
\text { (verbatim quotes from the } \\
\text { questionnaires) }\end{array}$ \\
\hline $\begin{array}{l}\text { ICT impacts on } \\
\text { sustainability }\end{array}$ & $\begin{array}{l}\text { Conceptual model describing ICT } \\
\text { impacts on sustainability, including } \\
\text { positive and negative impacts. }\end{array}$ & $\begin{array}{l}\text { "ICT can be part of the } \\
\text { problem as well as part of } \\
\text { the solution." }\end{array}$ \\
\hline $\begin{array}{l}\text { Material resources for } \\
\text { ICT hardware: Informal } \\
\text { recycling }\end{array}$ & $\begin{array}{l}\text { Report on informal recycling of } \\
\text { electronic waste in India, China, and } \\
\text { South Africa. }\end{array}$ & $\begin{array}{l}\text { "That there is actually } \\
\text { process of informal } \\
\text { recycling and how it is being } \\
\text { done }[\ldots . . .] \text { that some } \\
\text { countries do this in such a } \\
\text { non sustainable way and } \\
\text { pollute their environment so } \\
\text { strongly really surprised } \\
\text { me." }\end{array}$ \\
\hline $\begin{array}{l}\text { ICT as an enabler: } \\
\text { Saving material and } \\
\text { energy: } \\
\text { Videoconferencing } \\
\text { example }\end{array}$ & $\begin{array}{l}\text { Report on a field experiment using } \\
\text { massive videoconferencing to connect } \\
\text { two conferences (speakers, audience, } \\
\text { coffee breaks) to avoid } \\
\text { intercontinental flights and the related } \\
\mathrm{CO}_{2} \text { emissions. }\end{array}$ & $\begin{array}{l}\text { "A two-site conference } \\
\text { saves a lot of } \mathrm{CO}_{2} \\
\text { emissions." }\end{array}$ \\
\hline $\begin{array}{l}\text { Resource } \\
\text { consumption: Global } \\
\text { distribution }\end{array}$ & $\begin{array}{l}\text { Statistics about the development of } \\
\text { global material extraction and the total } \\
\text { material demand (including indirect } \\
\text { resource flows) of countries that are } \\
\text { considered service economies. }\end{array}$ & $\begin{array}{l}\text { " } 67 \% \text { of the resources from } \\
\text { nature for one single person } \\
\text { are extracted abroad." }\end{array}$ \\
\hline $\begin{array}{l}\text { Rebound effect: } \\
\text { General concept }\end{array}$ & $\begin{array}{l}\text { Introduction to the concept and } \\
\text { empirical evidence of energy rebound } \\
\text { as well as time rebound effects. }\end{array}$ & $\begin{array}{l}\text { "Increased efficiency does } \\
\text { not necessarily contribute to } \\
\text { reduced overall } \\
\text { consumption." }\end{array}$ \\
\hline
\end{tabular}

Table 4 briefly summarizes the contents of the lecture behind the clusters, i.e, the content that led to the insights that were then assigned to the respective cluster by the cluster analysis. For 
each cluster, it turned out that there was just one piece of content that had led to all insights reported that became part of this cluster. The content could be identified based on the data from questionnaires. All five clusters contain insights from both groups of subjects (those at $\mathrm{UZH}$ and those at $\mathrm{KTH}$ ). We therefore consider this result relatively robust with regard to the differences between the two courses and the students attending them.

To summarize the results, our study found that the most effective contents in the teaching materials - in terms of how strongly they motivated students to engage with SD and to reflect on sustainability issues - are as follows:

- A conceptual framework of positive and negative impacts of ICT on SD

- Real-life reports on the recycling of ICT hardware, with a focus on informal recycling in developing countries

- Real-life reports on using ICT to reduce greenhouse gas emissions, e.g., by videoconferencing

- Statistical data on the total material demand of modern economies

- Historical evidence for rebound effects

\section{Discussion}

This exploratory study identified course contents that motivate students on ICT-related study programs to engage with the topic of SD. What do the results contribute to meeting the challenges of introducing the topic of SD into education in the field of ICT, as they have been described in literature?

The study focused on motivation because motivation is considered a major challenge when introducing the topic of SD into ICT courses at universities (Özkan and Mishra, 2015). Our results show that certain topics connecting SD and ICT are thought-provoking for many students and have the potential to motivate them to engage with sustainability. By identifying the "golden nuggets", the study revealed which parts of the lectures, which topics, and which examples had the greatest potential to motivate students on ICT-related programs to engage with the topic of SD.

Another, related challenge is to provide practical examples of how ICT can be used to foster SD (Eriksson and Pargman, 2014). The results suggest that the material produced in the course of this project represents appropriate teaching material in this regard. We are currently transforming the material into a format that can be shared and hope that academics from other universities, in particular members of the growing ICT4S community, will provide further practical examples that can be used in teaching.

A third challenge mentioned in literature is the teaching of systems thinking, which plays an important role in teaching sustainability, in particular when the fields of ICT and SD are to be combined. Systems thinking can build a bridge between computational thinking and sustainable practice (Easterbrook, 2014). Teaching systems thinking is a huge challenge. Our results provide some evidence that the concept of the "rebound effect" provoked students to think about technical efficiency in a new way. Many of them formulated the insight that, when a good or service can be produced with less resource input (i.e., more efficiently), demand can 
Accepted author manuscript of the article:

Lorenz M. Hilty, Patrizia Huber, (2017) "Motivating students on ICT-related study programs to engage with the subject of sustainable development", International Journal of

Sustainability in Higher Education, https://doi.org/10.1108/IJSHE-02-2017-0027

increase, which partly compensates or even overcompensates for the expected resource savings. The rebound effect can be considered an introductory example to systems thinking.

The reasons why the "golden nuggets" were motivating cannot be derived from our data. Inline with the results cited from Mulder et al. (2015) rearding negative messages, we can only suspect that the two-sided role of ICT in the conceptual framework (including both positive and negative impacts of ICT for sustainability) and the positive message of reducing emission with videoconferencing made an important contribution to the overall motivation of the students to the topic. The other tree "golden nuggets", although conveying a strong negative message, still leave scope for potential change: recycling of ICT hardware can be improved, the total materials demand of rich countries could in principle be reduced (by help of ICT), and rebound effects are based on decisions consumers make. Looking for a common feature of the "golden nuggets", it can be said that they are surprising and that the problems they decribe leave room for the students to influence their future. This interpretation has been confirmed by the personal feedback of some students who explicitly acknowledged that the course was important for them to reflect about their individual responsibility for future developments.

A limitation of our study is that the data are inconclusive with regard to the persistence of the motivating effect (i.e., how long the students were motivated to engage with SD after the lecture), nor can we draw any conclusions about potential interactions between the contents.

Including SD-related content in ICT-related programs is, of course, only a small step towards the general goal of establishing SD in higher education. Viewed from a broader perspective, not only should curricula of many programs be adapted, but institutions must be transformed. The success of this will depend on the motivation of people in different roles - their openness for changing their perspective and their willingness to think and act in new ways (Mulder, 2012).

Our study is the first empirical investigation into the teaching of SD in the context of ICT. However, it has a number of limitations. We are aware of the fact that the generalizability of the results is limited due to several reasons. The first reason is the small sample size: Evaluating more instances of the courses described or reproducing the courses with a larger number of students would certainly lead to more representative data. Second, the qualitative content analysis used to code the formulations of insights may not be free of subjective bias. By providing the original formulations of the insights and their resulting assignment to clusters in the supporting information, we give the readers the opportunity to make their own judgment. Finally, our assumption that there is no effect of social desirability on response behavior might be wrong. We cannot completely rule out such an effect despite the anonymity of the questionnaires, as all subjects were participants in the lectures and may have been influenced by the assumed expectations of the lecturer

Due to these limitations, the results of our study should be interpreted with some caution. We hope that they will nevertheless contribute to the integration of the topic of SD into higher education in the field of ICT and inspire new research in this area. 
Accepted author manuscript of the article:

Lorenz M. Hilty, Patrizia Huber, (2017) "Motivating students on ICT-related study programs to engage with the subject of sustainable development", International Journal of

Sustainability in Higher Education, https://doi.org/10.1108/IJSHE-02-2017-0027

\section{CONCLUSION AND OUTLOOK}

This exploratory study identifies what sort of content can motivate students on ICT-related study programs to engage with the subject of sustainable development (SD). Data was generated by evaluating courses at UZH and KTH in the field of ICT and sustainability.

Our main conclusion is that it is possible to motivate the students to engage with the topic of SD by presenting them with content that builds bridges between their own field of study and issues of sustainability, and leaves scope for responsible action.

As already mentioned, identifying meaningful and motivational content is a necessary first step in preparing a learning unit. Our results may provide some guidance for this first step in teaching practice. Future research should address the next step, i.e., focus on the influence of the learning environment on the motivation of students to engage with SD, including the selection of teaching methods, classroom formats and performance assessments.

\section{REFERENCES}

Cai, Y. (2010), "Integrating Sustainability Into Undergraduate Computing Education", in Proceedings of the 41st ACM technical symposium on Computer science education, Wisconsin, March 10-13, 2010, ACM New York, pp. 524-528.

Coroama, V.C., Hilty, L.M. and Birtel, M. (2012), "Effects of Internet-Based Multiple-Site Conferences on Greenhouse Gas Emissions", Telematics and Informatics, Vol. 29 No. 4, pp. 362-374.

Coroama, V.C., Hilty, L.M., Heiri, E., Horn, F. (2013), "The Direct Energy Demand of Internet Data Flows", Journal of Industrial Ecology, Vol. 17 No. 5, pp. 680-688.

Drayson, R. Bone, E., Agombar, J. and Kemp, S. (2013), "Student attitudes towards and skills for sustainable development", A report for the Higher Education Academy, available at: https://www.heacademy.ac.uk/sites/default/files/esd_student_attitudes_2013_v4.pdf (accessed October 26, 2016).

Easterbrook, S. (2014), "From Computational Thinking to Systems Thinking: A conceptual toolkit for sustainability computing", in proceedings of the 2nd International Conference on Information and Communication Technologies for Sustainability (ICT4S 2014), Stockholm, Sweden, 2014, Atlantis Press, pp. 235-244.

Eriksson, E. and Pargman, D. (2014), "ICT4S reaching out: Making sustainability relevant in higher education", in proceedings of the 2nd International Conference on Information and Communication Technologies for Sustainability (ICT4S 2014), Stockholm, Sweden, 2014, Atlantis Press, pp. 40-47.

Erdmann, L. and Hilty, L.M. (2010), "Scenario Analysis. Exploring the Macroeconomic Impacts of Information and Communication Technologies on Greenhouse Gas Emissions", Journal of Industrial Ecology, Vol. 14 No. 5, pp. 824-841.

GeSI Global e-Sustainability Initiative \& Boston Consulting Group (BCG) (2012),"SMARTer 2020: The Role of ICT in Driving a Sustainable Future", available at: 
Accepted author manuscript of the article:

Lorenz M. Hilty, Patrizia Huber, (2017) "Motivating students on ICT-related study programs to engage with the subject of sustainable development", International Journal of Sustainability in Higher Education, https://doi.org/10.1108/IJSHE-02-2017-0027

https://www.telenor.com/wp-content/uploads/2014/04/SMARTer-2020-The-Role-of-ICT-inDriving-a-Sustainable-Future-December-2012._2.pdf (accessed 30 September 2017).

GeSI Global e-Sustainability Initiative. (2015), "SMARTer2030: ICT Solutions for $21^{\text {st }}$ Century Challenges”, available at: http://smarter2030.gesi.org (accessed 30 September 2017).

Hilty, L. M. and Bieser, J. T. C. (2017), "Opportunities and Risks of Digitalization for Climate Protection in Switzerland“", Report to Swisscom AG and WWF Switzerland, University of Zurich.

Hilty, L. M. and Hercheui, M. (2010), "ICT and Sustainable Development", in Berleur, J., Hercheui, M., Hilty and L. M. (EDs.), What Kind of Information Society? Governance, Virtuality, Surveillance, Sustainability, Resilience, 9th IFIP TC 9 International Conference, HCC9 2010 and 1st IFIP TC 11 International Conference, CIP 2010, Held as Part of WCC 2010, Brisbane, Australia, September 20-23, 2010, Proceedings, Springer, Berlin Heidelberg New York, pp., 227-235.

Hilty, L. M., Wäger, P., Lehmann, M., Hischier, R., Ruddy, T. and Binswanger, M. (2004), "The future impact of ICT on environmental sustainability", Fourth Interim Report - Refinement and quantification, Institute for Prospective Technological Studies (IPTS), Sevilla.

Hilty, L.M. and Aebischer, B. (2015), "ICT for Sustainability: an Emerging Research Field", in Hilty, L.M. and Aebischer, B. (Eds.), ICT Innovations for Sustainability. Advances in Intelligent Systems and Computing, Vol. 310, Springer, Switzerland, pp. 3-36.

Hilty, L.M. and Huber, P. (2017). Supporting information for "Motivating Students on ICTrelated Study Programs to Engage with the Subject of Sustainable Development", available at: https://files.ifi.uzh.ch/hilty/SI/motivating_students/

Hilty. L. M. (2008). Information Technology and Sustainability: Essays on the Relationship Between ICT and Sustainable Development, Books On Demand.

Hsieh, H.-F. and Shannon, S.E. (2005), "Three Approaches to Qualitative Content Analysis", Qualitative Health Research, Vol. 15 No. 9, pp. 1277-1288.

Issa, T., Issa. T. and Chang, V. (2014), "Sustainability and Green IT Education. Practice for Incorporating into the Australian Higher Education Curriculum", The International Journal of Sustainability Education, Vol. 9 No. 2, pp. 19-30.

Klafki, W. (1967), "Didaktische Analyse als Teil der Unterrichtsvorbereitung", in Roth, H. and Blumenthal, A. (Eds.), Grundlegende Aufsätze aus der Zeitschrift Die Deutsche Schule, Hermann Schroedel Verlag, Hannover, pp. 5-34.

Klimova, A., Rondeau, E., Andersson, K., Porras, J., Rybin, A. and Zaslavsky, A. (2016), "An international Master's program in green ICT as a contribution to sustainable development", Journal of Cleaner Production, Vol. 135, pp. 223-239.

Laitner, J.A., Knight, C.P., McKinney, V., Ehrhardt-Martinez, K., (2009), "Semiconductor technologies: The potential to revolutionize U.S. energy productivity", Washington, DC: American Council for an Energy-Efficient Economy.

Mann, S., Lopez, M., Lopez, D. and Smith, N. (2015), "Educating for ICT4S: Unpacking sustainability and ethics of ICT student intakes", in proceedings of the 29th International Conference on Informatics for Environmental Protection (Envirolnfo 2015) and the Third ICT for Sustainability (ICT4S 2015), Copenhagen, Denmark, 2015, Atlantis Press, pp. 229-241. 
Lorenz M. Hilty, Patrizia Huber, (2017) "Motivating students on ICT-related study programs to engage with the subject of sustainable development", International Journal of Sustainability in Higher Education, https://doi.org/10.1108/IJSHE-02-2017-0027

Mickoleit, A.(2010),"Greener and Smarter: ICTs, the Environment and Climate Change", OECD Green Growth Papers, No. 2010/01, OECD Publishing, Paris.

Mulder, K.F., Ferrer, D., Segalas, J., Kordas, C.O., Nikiforovich, E. and Pereverza, K. (2015), "Motivating students and lecturers for education in sustainable development", International Journal of Sustainability in Higher Education, Vol. 16 No. 3, pp. 385-401.

Mulder, K.F., Segalàs, J. and Ferrer-Balas, D. (2012), "How to educate engineers for/in sustainable development", International Journal of Sustainability in Higher Education, Vol. 13 No. 3, pp. 211-218.

Özkan, B. and Mishra, A. (2015), "A Curriculum on Sustainable Information Communication Technology", Problems of sustainable development, Vol. 10 No. 2, pp. 95-101.

Pargman, D. and Eriksson, E. (2013), "It's not fair! - Making students engage in sustainability", paper presented at the 6th International Conference on Engineering Education for Sustainable Development (EESD13), 22-25 September, Cambridge, UK, available at:

https://www.researchgate.net/profile/Daniel_Pargman/publication/286442227_It's_not_fair__making_students_engage_in_sustainability/links/566950d908ae193b5fa266ed.pdf (accessed December 8, 2016).

Som, C., Hilty, L.M., Köhler, A. R. (2009), "The Precautionary Principle as a Framework for a Sustainable Information Society", Journal of Business Ethics, Vol. 85 No. 3, pp. 493-505.

Sterling, S. (2004), "Higher education, sustainability, and the role of systemic learning", in Corcoran, P.B. and Wals, A.E.J. (Eds.), Higher education and the challenge of sustainability. Problematics, Promise, and Practice. Kluwer Academic Publishers, Dordrecht, pp. 49-70.

Ward, J. H.(1963), "Hierarchical grouping to optimize an objective function", Journal of the American Statistical Association. Vol. 58, pp. 236-244 